\title{
Testing time for gene patents
}

\author{
A surprising US court decision highlights the need to modernize gene-patenting practices \\ if patients are to benefit from advances in genetic research.
}

T he idea of awarding patents for specific gene sequences has been a contentious subject since at least the early 1990s, when it first became technologically possible to generate such sequences in large numbers. But US courts have consistently upheld these patents. Even in Europe, where the practice is particularly controversial, gene patenting has been codified into law since 1998. For better or worse, gene patents had seemed destined to be a settled part of the intellectual-property landscape.

Until 29 March, that is, when the US District Court for the Southern District of New York shocked the biotech community by invalidating patents covering mutations in the BRCA1 and BRCA2 genes that are used to assess the risk of breast and ovarian cancer. Myriad Genetics, a company based in Salt Lake City, Utah, holds exclusive licences on these patents and has aggressively defended them. In 2009, a group of patients, researchers and clinicians sued Myriad, asserting, among other complaints, that the patents hamper medical research. And District Court judge Robert Sweet largely agreed.

Beyond the ruling's power to make headlines, industry observers and legal experts see little chance that it will pose a real threat to gene patents. Not only are US courts outside the boundaries of New York's southern district not compelled to follow Sweet's precedent, but Myriad Genetics has pledged to appeal. The case will next be heard in the Court of Appeals for the Federal Circuit in Washington DC, which many observers feel favours patent holders.

Nevertheless, the decision does reflect growing concern about the impacts of gene patents on genetic testing. As the biotech industry inches closer to the long-anticipated era of personalized medicine, genetic tests promise to exert increasing influence in the clinic. But fully realizing that promise will require a view of gene patenting that is considerably more sophisticated than the one-size-fits-all standard that now prevails.

Genetic testing is undergoing a revolution. Classic tests relying on mutations in one or two genes, such as the BRCA1 and BRCA2 tests, are giving way to complex analyses involving many genetic signatures. Tests for a genetic heart condition called long QT, for example, now assay a dozen genes. Eventually, moreover, these complex analyses will themselves give way to whole-genome sequencing. Strict enforcement of single-gene patents in this landscape could ensnare genetic tests in a patent thicket - a tangled web of patents that would have to be negotiated before a given test could be performed. Such a situation threatens to hinder innovation.

There are also legitimate concerns that gene patents can limit patient and researcher access to genetic tests. This need not always be the case: tests for mutations associated with cystic fibrosis are patented, and the patents licensed to many companies. Those companies seem to have managed to turn a profit on the tests without creating a monopoly.

But in light of these concerns, an advisory committee to the US Department of Health and Human Services recently embarked on an analysis of the impact of gene patents on genetic testing. Its report, finalized in February, distinguishes between the use of a gene patent to cover a genetic test - in which the tester simply observes the sequence of a gene - and the use of that patent to protect investment in developing biotherapeutics, when patent holders use genetic information as a platform for invention. Given this distinction and the importance of preserving access to gene tests in the clinic, the committee recommended that gene-patent rights should not be enforced when they are violated in the course of research or genetic testing.

This proposal leaves many details still to be hammered out - and in any case it faces an uncertain future. Health-department secretary Kathleen Sebelius has yet to decide whether to recommend that Congress adopts the changes - and no bill has yet been introduced. But the proposal has already prompted a sharp outcry from biotechnology lobbyists and some members of Congress, who fear that it could hurt the nascent genetic-testing industry. Nevertheless, the advisory committee has provided one way forward. But whichever way they choose, Sebelius, Congress and the biotechnology industry should act without delay, implementing the basic principle of access to valuable genetic information for patients and researchers alike.

\section{Winners take all}

\section{Scientific competition is lacking in Japan, and efforts to increase it are not always best focused.}

I $\mathrm{n}$ country such as Japan, where personal loyalties are strong and university pedigrees are often akin to a family bond, objective evaluation of grants can be a challenge.

That is perhaps one reason why Japan has historically distributed comparatively little of its science funding through competitive grants, preferring instead to spread it more evenly by funnelling the money into the basic operating budgets of universities and research institutions. In 2009, only $13.8 \%$ of the country's reseach funding was allocated through competitive grant schemes - up from just $8.9 \%$ in 2002 - a considerably lower proportion than in the United States.

Although this approach might seem democratic and fair, Japanese 